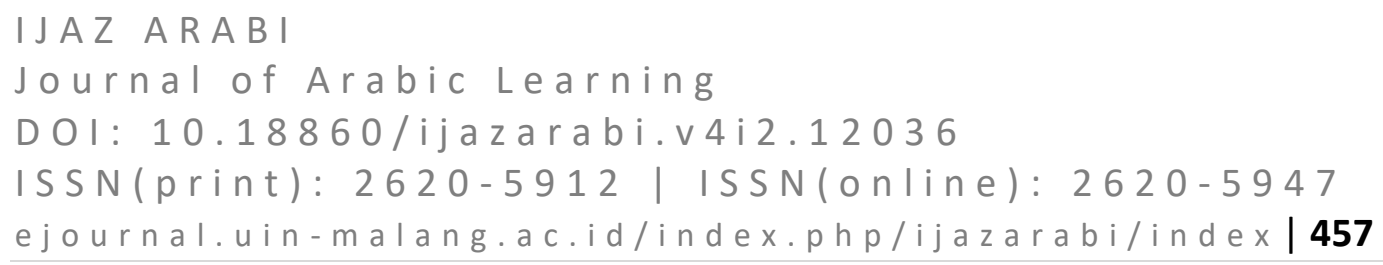

\title{
Revisiting The Theory Of Translation: Investigating The Translation Divan-e Hafiz
}

\author{
Tribhuwan Kumar', Triyo Supriyatno \\ Prince Sattam Bin Abdulaziz University, Al Kharj, Saudi Arabia ${ }^{1}$, \\ Universitas Islam Negeri Maulana Malik Ibrahim Malang, Indonesia ${ }^{2}$ \\ t.kumar@psau.edu.sa, triyo@pai.uin-malang.ac.id
}

\begin{abstract}
Translation theory offers a complex phenomenon when source language (SL) is transported and communicated in the target language (TL). Therefore, it is a grave concern for a translator to utilize equivalent ideas in another language. The current investigation tried to analyze lexical collocations in Arabic literature poems from Divan-e Hafiz and compare interpretations made by A J. Arberry (1905-1969) and H. W. Clarke (1840-1905) in request to find the most widely recognized methods the two interpreters utilized and to uncover the benefits and imperfections relating to each technique. This paper investigated that strict, social, and semantic collocations are separately the most troublesome word mixes for interpreters to achieve the cycle. It further delineated that the most incessant methodology taken by the two interpreters was in the interpretation of the same word and, in a few cases, a decrease of the lexical relationship to limit contorting the structure, complex and semantic examples highlighted in poems while making a similar impact in the TL. This phenomenon provides an overview of how to teach Arabic literature translation well.
\end{abstract}

Keywords: Interpretation of Verse; Lexical Collocation; Strict Collocation; Semantic Highlights; Equal Impact

\section{INTRODUCTION}

As a distinctive sort of tasteful capacity of language, the interpretation of poetry is constantly viewed as more bewildering than the interpretation of some other writings (Ajmal \& Kumar, 2020; Kumar, 2020). There has consistently been much contest about strategies that can be utilized to safeguard the artist's message and the uniqueness to produce comparable impacts in the objective language. A portion of the various issues interpreter experiences during the cycle is using etymological instruments that are verifiably entwined with language and culture. The verse involves etymological nuances like collocations that need interpretation. Language is a cultural-based concept (Mahmood et al., 2020; Khan et al., 2020). The fact of the matter is that collocations are basically and thoughtfully language and culture explicit, and an interpreter should manage them exactly to keep up social and tasteful qualities. As a distinct form of the delicious power of language, the interpretation of poetry is often regarded as more astonishing than the interpretation of other texts. Some of the various problems a translator encounters in making it are due to etymological instruments. Poems include etymological 


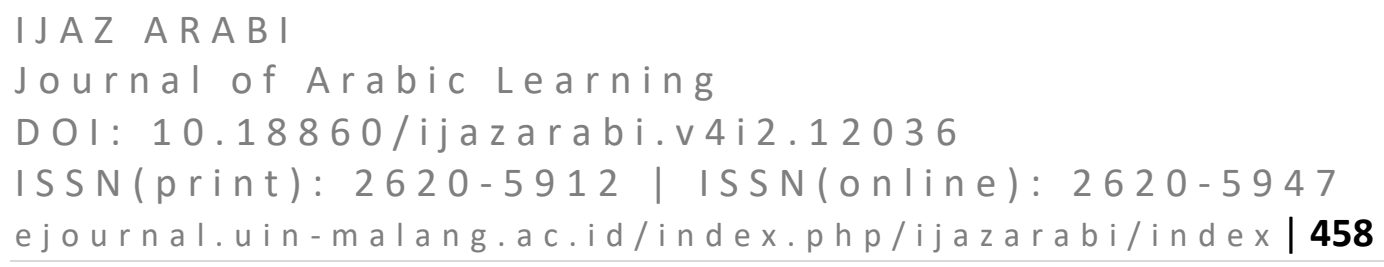

nuances, for example, a combination of great ideas that tend to be interpreted. Clarke (1840-1905) asks for the best-known techniques used by two translators and to discover the advantages and disadvantages associated with each process. This paper investigates such strong social and psychological connections. The researchers also pointed out that the less frequent method used by the two translators was the exact translation terms and, in a few cases, a decrease in lexical relationships to limit formation, detailed prominence, and network construction during the effects of TL.

However, there is still debate as to whether writing can be a translation. It is a critical issue in interpreting the theological work, especially since the verse is a particular phonetic highlight of the editorial style used to make it different from the text. These poetic highlights are closely tied to a particular culture, religion, and conviction in general. The possibility that a halfway verse might mix in interpretation might be somewhat honest because no one is the same when contrasting two dialects.

In any event, they were thought to be arbitrary, difficult to understand, describe and edit themselves, difficult to identify. Although they are considered one of the subtleties of language, we can speculate how practical the cultural knowledge of the source text might be in grasping the meaning of conflicts in the sense that, like many other aspects of language, they are highly bound by culture. Therefore, a translator should reach a complete understanding of vocabularies and their contexts of use in SL and TL. Although the article's focus is on the semantic selection that supports the equivalent of impact on TL readers such as those from the SL, it is easier to appreciate if collisions are appropriately understood.

Collocation is the concept of word coincidence, where some words appear predictably next to or within a certain number of words from each other; the usual string considered is four words on each side of ' $r$ the word mark, sometimes called a nine-word span. Thought involves phrases in a syntactic connection (e.g., action word object: 'make' and 'choice'), lexical match (antonyms and synonyms), or things language (linguistic phrase or phrase). The actual phrase is co-event of things, modifier, action or qualitative word, for example, strict (as opposed to unbending), or he pricks his finger This (rather than penetrating or penetrating). Colligation is the co-event of something. It is the relational description of words, some language highlights, for example, a kind of compliment close to from coal, or from management action from about. The importance of collocation in terms of ease of interpretation can be seen as central. In addition, collocations are a collection of words used to create lexical joins in a text, which can be powerful.

For structuralism, there are three kinds of translation: first, intralingual translation, paraphrasing, or rephrasing within one language. The second one is Interlingua which is a summary or rephrasing between two languages. The last one is intersemiotic translation that is rewording or paraphrasing into a sign system. In this research study, the researcher is worried about Interlingua translation between Urdu Language and the English language (Jacobson, 1959). Nida (1969) states 
translation is the reproduction of receptor language, which is target text (TT) in the closest usual equivalent of the source text (ST). Importance is given to sense and style. He is more absorbed because of equivalence in translation, both at the level of stylistics and semantics. She sees translation as a renewal of an identical response of the ST in the TT. In the same way, this view of translation overlaps with the view of Tytler (1993), which also favors a full equivalence at the levels of sense and effect as optional that an excellent translation has the soul of the unique text. The essence of the basis is transfused so that it is felt then detained by the innate of linguistic.

Other philosophers defined it as an aim being required to translate or what issues should be considered when passing through this process. Mouin (2007) opines that to translate is not only to take care of the text's linguistic, diagram, or structural sense. However, one should reflect the semantics of the note along with its culture, setting, and retro. In a husk, these numerous descriptions from many viewpoints vary in positive features as deliberated above. Some of them present the aim of the translation; few of them look to semantics and some to style. Some describe the translator as an intermediary. Moreover, some focus on the general aspects of Interlingua, intralingual, and intersemiotic as proposed by Jacobson (2000). This present study is concerned with an examination and account of translation from Urdu text that is source text to English manuscript that is board text under the leadership of Baker's theory of non-equivalence at various levels discussed in the next chapter of this research study. The translation is always understood to transmit a message or meaning in writing from one language to another. "Translation is expressed in another language (or target language) by protecting another, source language, terminology, and style equation," says dubiously. It is to develop a theoretical framework for translation theories, models, and analogies, understand translation systems, and determine its validity for application in real-life translation.

Define system is the theory of a scientist that is considered a model when passed on to another. According to Larson (1984: 15), two main types of translation are classified into, i.e. form-based and meaning-based translation. A form-based translation source tries to follow the language format and is known as a word translation. While a meaning-based translation receptor makes every effort to communicate the text meaning of SL in natural forms of language, it is called idiomatic translation Nida and Taber in their book. Theory and practice of translation (1969) list some of the universal features of the text that should be taken into account in translation:

In this model, nada divides the translation process into the encoding phase and transmits the message $(\mathrm{m})$ from source to target language ( $\mathrm{x}$ to $\mathrm{y}$ ). In an encoding phase, this model is transparent and has meaning in multiple. Ways Eugene Nida gave two types of equivalence: formal and dynamic. Formal equivalence is the word-for-word translation (translating the meanings of words and phrases in a more literal way) keeping literal conformity. 
Journal of Arabic Learning

DOI: $10.18860 / \mathrm{ijazarabi.v4i2.12036}$

ISSN(print): $2620-5912$ | ISSN(onIine): $2620-5947$

ejournal.uin-malang.ac.id/index.php/ijazarabi/index/460

Formal equivalence is described as focusing attention on the message itself in both form and content. It is the word-to-word translation of the text. Roman Jackson: meaning and nature of language making: Many scholars have explained a translation differently. Moreover, some classification of translation types is also present by some experts. For example, Roman Jacobsen has classified the translation into three categories.

\section{METHOD}

The current study examined all Hafiz's lexical collocations in "Divan" and compared the corresponding translations between two English translators, A.J. Arberry and $\mathrm{H}$. Wilberforce Clarke to assess the extent that religious and cultural information has been supportive of collocation translations. There is great number of collocations analysed in their translation. However, in order to provide an analysis in this research, 8 cases were selected and randomly classified by category of religion, culture and semantic. The next section discusses a translation study that use Newmark's (1981) “equivalent effect" notion to replicate Source Language into target language while preserving its religious, cultural, and semantic features. The section below will examine several techniques for carrying out the equivalence task in translation used by the two translators.

\section{RESULTS AND FINDINGS}

To investigate the information, first, the Persian lines, including the strongly composed collocations under the examination are given together the literal interpretation of the collocations-next, the two English interpretations from A. Then, J. Arberry (shown as A) and H. Wilberforce Clarke (appeared as B) are given trailed by investigating and assessing the interpreters' techniques. The vocabulary phrases used by Hafiz in his crucial work "Divan" were analyzed. Their comparative interpretations by two British translators, A. Wilberforce Clarke, compared all together to find out to the extent to which social and coherent data helps to interpret the phrases. Out of all of the phrases examined, 15 cases were selected messily and put in strict, social, and semantic categories to introduce the investigation. It adopts strict, social, and semantic SL versioning into TL in a way that reproduces the SL impact in TL.

\section{Intra Langue Translation Or Re-Recording}

Interlingua translation interprets the verbal symbols of the language: Other symbols in the same language; expressions or texts are translated into different expressions or texts in the same language; Describing sentences, simplifying a novel, and presenting poems in prose are examples of intra long translation.

\section{Interlingual Translation Or Translation Appropriate}

The interlingual translation is the interpretation of verbal symbols of language: Through other languages; It can be bilingual or multilingual; Moreover, 
IJAZ ARAB I

Journal of Arabic Learning

DOI: $10.18860 / \mathrm{ijazarabi.v4i2.12036}$

ISSN(print): $2620-5912$ | ISSN(onIine): $2620-5947$

ejournal.uin-malang.ac.id/index.php/ijazarabi/index/461

interlingual translation can be seen in translating literary creations in different languages.

\section{Inter Semiotic Translation Or Transmission}

Inter Semitic translation is the interpretation of verbal symbols. Language by non-verbal sign system signs involves using signals or signals to communicate; Ben's semiotic translation can be applied in some systems such as sign language or traffic signs. Several studies have been conducted on collocation and collocation issues in interpretation. According to Newmark (1988), "The problem of collocation interpretation is due to two important reasons. One is that there is only a self-assertive relationship between the segment of collocation and its importance.

Bread Cook (1992) similarly alludes to the subjective link between the components of salmon and their overall meaning. She accepts A progression measure that is common in all languages. She likewise sources the difficulty of interpreting salmon. It specifies that the salmon design of the language and target language is laid out uniquely. Another consideration to consider when dealing with translation integration is unique; the more elaborate a term, the shorter its interdependent scope.

Lyons (1997) believes that the discrimination of a collocation should be considered in all respects. Moreover, the segregation of its components does not provide a fair balance in their integration. Benson et al. (1986), Nattinger and De Carrico (1992) view integration as repetitive word combinations taking a down-toearth view of integration. Cowie (1993) and Robins (1971) (cited Herbst, 1996) are classified as "consistent consistency of word in a language with other words in sentences, for example, white espresso, jealous green and girlfriend" (Addison, 1983); The structure of a book can be difficult if there are large enough examples of standard comparison texts. A similar text can be created by examining the relationship between lexical combinations and subject sequences/comments. Addison asserts that when a lexical set frequently occurs within the title part of a sentence, the lexical set will be regarded as speaking to the point of the content, which can go with the overall content theme. Most of the descriptive researchers focus actually on better content will be the result of translation. They suggest that when faced with a merger, the interpreter should seek equal merger in TL.

To examine the information, a Persian line containing the impressively constructed collocations under investigation is first presented with a literal interpretation of the collocations, and then two English interpretations from A.

\section{Religious Collocations}

One must consider that collecting collocations is a mixture of specific words. Strict parables and references to traditions When these words are constructed with different words, the entire collocation gains the importance of options and is usually quite difficult to decipher. is. A small number of writers aim to move because they have a rich group of information about religion Religious 


\section{IJAZ ARAB I}

Journal of Arabic Learning

DOI: $10.18860 / \mathrm{ijazarabi.v4i2.12036}$

ISSN(print): 2620-5912 | ISSN(onIine): 2620-5947

ejournal.uin-malang.ac.id/index.php/ijazarabi/index

messages in a highly viable and sensitive way. The following is used in Hafiz's poetry Here are some examples of religious collocation

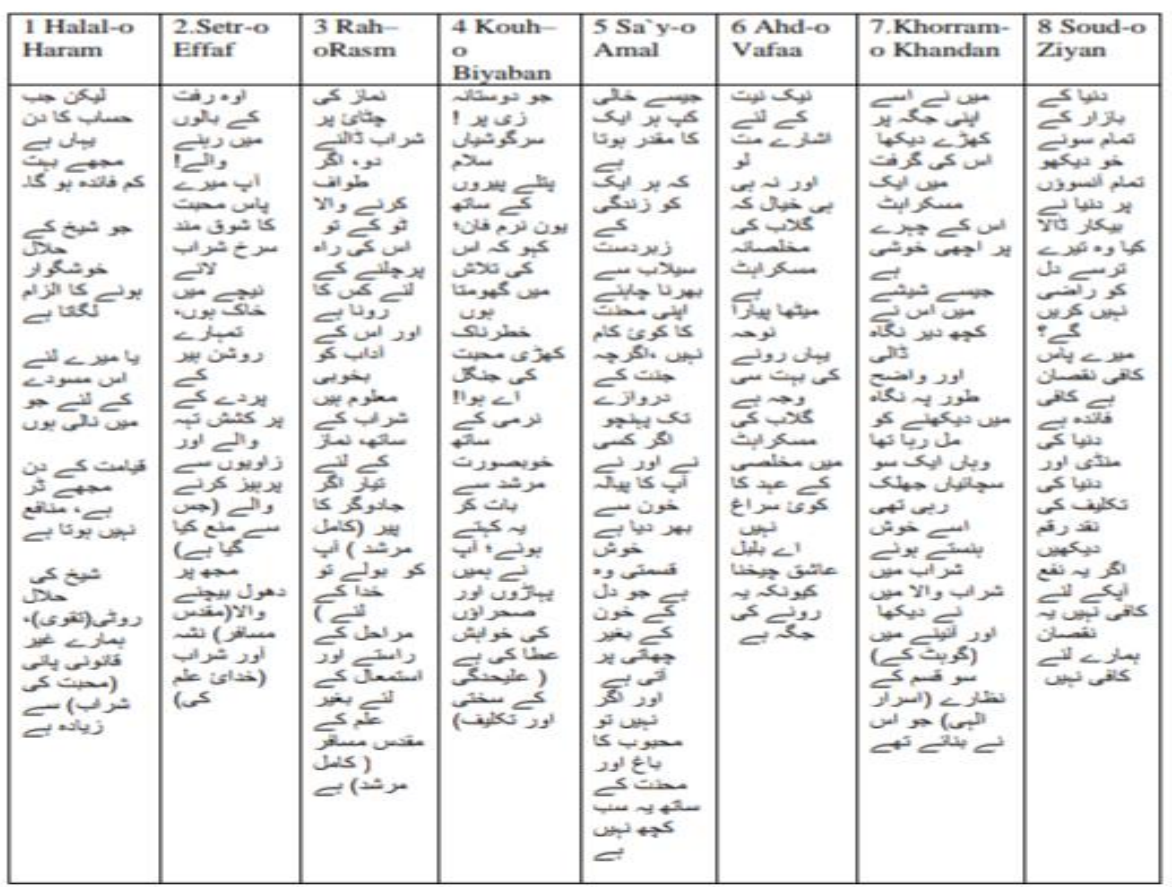

Table 1. Halal-o Haram

\section{Translation: $(A)$}

"But when the Day of Reckoning is here,

I fancy little will be the gain

That accrues to the Sheikh for his lawful cheer,

Or to me for the draught forbidden I drain."

\section{Translation: $(B)$}

"On the day of up-rising (the resurrection), I fear, a profit taketh not.

The lawful bread (piety) of the shaikh, more than the unlawful water (wine of love) of ours."

Two parts of the strict phrase "Halal-o Haram" are in a shameful relationship, implying "a deed in full accordance with / against Islamic spirit and religious obligation". Both translators created the same base term "lawful" but used distinct collocates for "forbidden" and "unlawful".

Table 2. Setr-o Effaf

Translation: $(A)$

"Oh dwellers in the halls of Chastity!

You brought Love's passionate red wine to me,

Down to the dust I am, your bright feet stept."

Translation: $(B)$ 


\section{IJAZ ARABI}

Journal of Arabic Learning

DOI: $10.18860 / \mathrm{ijazarabi.v4i2.12036}$

ISSN(print): $2620-5912$ | ISSN(online): $2620-5947$

ejournal.uin-malang.ac.id/index.php/ijazarabi/index/ 463

"The dwellers of the sacred fold of the veilingand of the abstaining (from what is forbidden) of the angles,

On me, dust-sitter (holy traveller), the intoxicating wine (of divine knowledge) cast."

The use of compound letters of Arabic origin such as "Setr-o Effaf" as marked on the line above, has become so common that Persian speakers automatically associate two identical parts. This word literally encompasses the word "setr" meaning "to cover the sins of others" and "effaf" which means "purity" and absolutely "holiness" and "purity" is said.To overcome the obstacle of translating this collocation, both translators, while knowing meaning, they have taken different approaches.

\section{Semantic Collocations}

This type of collocation is largely based on common sense and is related to the fact that the base means a certain means. In terms of the element that occurs in conjunction with it. In a semantic compound the two words are separated mainly by nouns and adjectives and because of their consensus, they belong to the same grammatical category.

Table 3. Rah-oRasm

\section{Translation: $(A)$}

"Let wine upon the prayer-mat flow, and if the taverner bids so;

Whose wont is on this road to go its ways and manners well doth know."

\section{Translation: $(B)$}

"With wine, becolour the prayer-mat- if the Pir of the magians (the perfect murshid) bid thee;

For of the way and usage of the stages (to God) not without knowledge is the holy traveller (the perfect murshid)."

According to Persian tradition, in the expression "Rah-o Rasm", the harp and its collection are identical meaning "the way to act". The collocational word was translated by Arberry as "ways and manners" with the two components sharing the same meaning characteristic. Clarke, on the other hand, chose the phrase "the way and usage" because he believes that the word "usage" does not adequately convey the concept of "rasm"

Table 4. Kouh-o Biyaban

Translation: $(A)$

"Go, friendly Zephyr! Whisp 'ring greet

Yon gentle fawn with slender feet;

Say that in quest of her I rove

The dangerous steeps, the wilds of love."

Translation: $(B)$

"O breeze! With softness speak to the beautiful fawn (the murshid), 


\section{IJAZ ARABI}

Journal of Arabic Learning

DOI: $10.18860 / \mathrm{ijazarabi.v4i2.12036}$

ISSN(print): 2620-5912 | ISSN(onIine): 2620-5947

ejournal.uin-malang.ac.id/index.php/ijazarabi/index | $\mathbf{4 6 4}$

\section{Saying: Thou hast given to us desire for the mountain and the desert"}

The phrase "Kouh - from Biyaban" in Persian language implies "careless spinning around". In the main translation "The dangerous soaks, the wild", Arberry must surely be expected to have done the same strange thing, but truth be told it represents the logical perspective on importance in lexical semantics as suggested in the source text. In introducing a second translation, using the phrase "the mountain and the desert", Clarke has first uttered a similar word, then is traced by an elaboration in brackets realizing it by a simple version in exactly the same words the importance cannot be shifted.

Table 5. Sa`y-o Amal

\section{Translation: $(A)$}

"Like an empty cup is the fate of each,

That each must fill from Life's mighty flood;

Nought thy toil, though to Paradise gate thou reach,

If Another has filled up thy cup with blood;"

\section{Translation: (B)}

"Fortune is that which, without the heart's blood, cometh to the bosom:

And, if not, the garden of the Beloved (gained) with effort and toil all this is naught."

The foundation and summation in the collocational term "Sa'y-o Amal" is a "committed" gathering. The parts of the term are so tightly tied that the chief interpreter likes to reduce the term into a single word; for example the "labor" thing which is, by all means, satisfactory to associate a similar significance to the SL phrase. Notwithstanding this, in the subsequent interpretation, Clarke has unnecessarily given a word-for-word version that occurs in an odd word crew for the perusers TL.

Table 6. Ahd-o Vafaa

\section{Translation: $(A)$}

"Take not for sign of true intent

Nor think the rose's smile sincere;

Sweet, loving nightingale, lament:

There is much cause for weeping here."

\section{Translation: $(B)$}

"In the smile of the rose, is no trace of thecovenant of fidelity:

O Bulbul-lover; bewail; for it is the place of wail."

In the "Ahd-o Vafaa" co-location structure, it appears it is clear to the interpreter that the focal point is correlated semantically with collecting for example 'to submit to someone's guarantee'. Nonetheless, Arberry wanted to use the descriptive phrase "real intent" as correspondence for Persian co-location and Clarke has adequately interpreted the co-location to the phrase "the treaty of consistency" as a sign of "fidelity" to keep the idea of it. However both will 


\section{IJAZ ARABI}

Journal of Arabic Learning

DOI: $10.18860 / \mathrm{ijazarabi.v4i2.12036}$

ISSN(print): 2620-5912 | ISSN(onIine): 2620-5947

ejournal.uin-malang.ac.id/index.php/ijazarabi/index/465

probably provide a satisfactory counterpart to move the SL significance segment to TL and appreciate the SL effect.

\section{Culture-Specific Collocations}

The meaning of the whole cannot be extrapolated from the constituent parts. In other words, someone who is unfamiliar with the culture in which the language is spoken should be unable to comprehend the entire text. On the other hand, culture-bound collocations are made up of vocabularies that are closely associated with the culture of the language that they are derived from. They can only be comprehended in the language they are used in, i.e. colloquial language. As a result, translators may encounter challenges while interpreting culturally constrained collocations.

Table 7. Hast-o Nist

\section{Translation: $(A)$}

"Nor with Is nor Is Not let thy mind contend;

Rest assured all perfection of mortal birth

In the great Is Not at the last shall end."

\section{Translation: $(B)$}

"Grieve neither at existence nor at non-existence: Be thy mind, happy.

For the end of every perfection that is - is non-existence."

The antonymous collocation"Hast-o Nist" connotes "life and death" in philosophy. These are two truths that are so inextricably linked that they cannot be separated.

Arberry has used the collocational term "Is and Is not", which is less influential than Clarke has used the term "existence and non-existence".

Table 8. Kwon-o Makaan

\section{Translation: $(A)$}

"What is wrought in the forge of the living and life

All things are nought! Ho! Fill me the bowl,

For nought is the gear of the world and the strife!"

\section{Translation: $(B)$}

"The produce of the workshop of existence and dwelling (the whole world) all this is naught;

Bring wine (of the love of God), for the goods of the world all this is naught."

"Kwon-o Makaan" which means "the whole world and whatever is in it" is a colloquialism. Because of its frequent use, it has lost its original meaning, resulting in an idiomatic term. Both translators used comparable equivalents in their translations. Arberry employed the collocational expression "living and life" which is neither colloquial nor idiomatic. In an attempt to create a comparable effect on TL readers, Clarke has generated a word-for-word translation followed by some definitions to compensate for the loss of meaning. 
IJAZ ARABI

Journal of Arabic Learning

DOI: $10.18860 / \mathrm{ijazarabi.v4i2.12036}$

ISSN(print): $2620-5912$ | ISSN(onIine): $2620-5947$

ejournal.uin-malang.ac.id/index.php/ijazarabi/index/466

\section{CONCLUSION}

This investigation aimed to analyze two English interpretations of Divane Hafiz's fasting as a Persian occupation. The article has been limited to lexical and cultural collocations as semantic devices with an alternate application when used in verse. The level of trouble in deciphering collocations is depended on the sort of collocation. Collocations related to strict settings seemed, by all accounts, to be the riskiest, so the two interpreters needed to adopt a few strategies to deal with them appropriately. In general, they would utilize counterparts that were more recognizable for the TL readers in request to domesticate the content while keeping up the message and style of the verse. Sometimes the interpreters favored an interpretation of the exact words followed by definitions to make the term more logical and amplify the impact in the factual content. Other troublesome collocations incorporated those identified with the way of life. No issues showed up in the case for a source text collocation. There was an identical in the objective language with similar significance. However, by and large, the significance or structure must be changed to become justifiable for the objective perusers and give equivalent impacts.

The most challenging type was collocations with semantic relations between the segments constructing them. More often than not, they presented no severe issue, and the interpretation of the exact words appeared to be satisfactory. In any case, for collocations with the interchangeable connection between the two sections, the interpreters liked to diminish the term into a word level. Yet, at times they go past their essential significance and embrace auxiliary importance to assume the job of a literary device which requested interpreter's thoughtfulness regarding utilize diverse drew nearer as examined to manage them adequately.

\section{REFERENCES}

Addison, J. C. (1983). Lexical collocation and topic occurrence in well-written editorials: a study in form. In A. E. Fantini (Ed.), The Growth of Word Meaning (pp. 69-91). Cambridge, MA: MIT Press.

Ajmal, M., \& Kumar, T. (2020). Inculcating learners' listening motivation in English language teaching: A case study of British education and training system. Arab World English Journal (AWEJ). 11(4), 409-425. DOI: https://dx.doi.org/10.24093/awej/vol11 no4.26

Arberry, A. J. (1947). Poems from the Divan of Hafiz. (Eng. Tr. Divan-e-Hafiz). Cambridge.

Baker, M. (1992). In Other Words: A Course Book on Translation. London: Routledge.

Benson, M. (1989). The structure of the collocational dictionary. International Journal of Lexicography, 2(1), 1-14.

Carter, R. (1998).Vocabulary: Applied Linguistic Perspectives (2nd Ed.). London: Routledge. 
Journal of Arabic Learning

DOI: $10.18860 / \mathrm{ijazarabi.v4i2.12036}$

ISSN(print): $2620-5912$ | ISSN(onIine): $2620-5947$

ejournal.uin-malang.ac.id/index.php/ijazarabi/index

Clarke, H. W. (1881). The Divan-i-Hafiz, (Eng. Tr. Divan-e-Hafiz).The office, Board of Examiners, Elysium Row. (Ed by Major H. S. Jarrett). Calcutta.

Cruse, D. A. (1986). Lexical Semantics. New York: Cambridge University Press.

Dechert, H. W., \& Lennon, P. (1989). Collocational blends of advanced second language learners: A preliminary analysis. Contrastive Pragmatics, 131168.

Firth, J. R. (1968). Descriptive linguistics and the study of English. Selected papers of JR Firth (1952-59), 96-13.

Gitsaki, C. (1996). The Development of ESL Collocational Knowledge. University of Queensland, Bangor.

Halliday, M. A. K., \& Hasan, R. (Eds.). (1976). Cohesion in English (English Language). Essex: Longman.

Herbst, T. (1996). What are collocations: sandy beaches or false teeth? English Studies 77(4), 379-393.

Khan, R.M.I., Shahbaz, M., Kumar, T., \& Khan, I. (2020). Investigating reading challenges faced by EFL learners at elementary level. REGISTER JOURNAL. 13(02), 277-292.

Kumar, T. (2020). Representation of victorian society in the poetry of Mary Howitt. Utopia y Praxis Latinoamericana. 25 (12), 215-221. DOI: http://doi.org/10.5281/zenodo.4280128.

Lyons, J. (1977). Semantics (Vol. 2). New York: Cambridge University Press.

Mahmood, R., Shah, A. H., \& Kumar, T. (2020). English language learning and its socio-cultural effects: A comparative study of private and government schools of Islamabad. Asian EFL Journal, 27 (3.3), 150-164.

Mollanazar, H. (1990). The role of collocation in translation, Unpublished. Tarbiyat Modarres University, Tehran.

Nattinger, J. R., \& DeCarrico, J. S. (1992).Lexical phrases and language teaching. New York: Oxford University Press.

Newmark, P. (1981). Approaches to translation. Oxford: Pergamon.

Newmark, P. (1988). A textbook of translation. New York: -Prentice-Hall.

Shahriari, Z. (1997). The restrictions of lexical collocations and translation. Islamic Azad University, Tehran.

Sinclair, J. (1991). Corpus, Concordance, Collocation. New York: Oxford University Press.

Stubbs, M. (1995). Collocations and semantic profiles: On the cause of the trouble with quantitative studies. Functions of Language, 2(1), 23-55. 